\title{
Perception of gender equality in new media ${ }^{1}$
}

\author{
Kübra Küçükşen ${ }^{2}$
}

\begin{abstract}
Introduction : Social gender is a concept that is used to describe the roles to be fulfilled, behavioral patterns and duties and responsibilities expected from males and females in socialization process according to the culture of the society where they live in different from biological gender. Media is a significant tool for determination and internalization of social gender roles. In parallel with social change and transformation, the change had in mass communication tools become effective in every field. New communication aspect called as new media provide opportunity for individuals to express themselves and present their opinions on every issue freely different from other mass communication tools.

Methods : In this study, it was aimed to investigate the comments made on the concepts of "gender equality" and "gender inequality" on the social sharing sites named Ekşi Sözlük and Uludağ Sözlük. The comments made over the concepts of "social gender equality" and "social gender inequality" in web site called "Ekşi Sözlük" and "Uludağ Sözlük" were reviewed during to 1 June- 15 September 2015 in this study and it was targeted to research the perception of social gender. For analyzing data, content analyzis was applied to comments.

Results :In the study, 105 comments made on Ekşi Sözlük and 39 comments made on Uludağ Sözlük in regard to the subject matter were categorized and analyzed as "gender equality/inequality" and "gender roles". According to the data attained from analysis of the study, as opposed to conventional media, it is seen that the comments made on gender are quite varied. Besides such comments which reduce women merely to a body, insult them, assert that they lack the knowledge, skills and competence for existing in the public sphere, comments exceeding the equalitarian viewpoint on the subject, grounding on justice and equity have been identified.

Discussion : Reflections of the conventional patriarchal mentality are evidently seen in the comments on Ekşi Sözlük and Uludağ Sözlük. Being an environment where an issue is discussed by people in several numbers and having quite different opinions in different perspectives, social networking sites provide an important source of knowledge to the forms of peoples' understanding and interpretation of social life. According to the data obtained in the research, the perception of social gender has still been produced in new media. However, it can be said that social gender perception is directed through the course where the understanding of "difference is not inequality" with an upper point of view exceeding the concepts of equality and inequality is grounded on in new media despite adopting an opponent discourse on the contrary to mainstream media.
\end{abstract}

Keywords: New media, social networks, gender, gender inequality, gender roles

\footnotetext{
1 The paper has been presented in as a oral presentation at a preliminary statege ICSER-International Conference on Social Sciences and Education Research days 29-31 October 2015, Antalya/Turkey

2 Assist. Prof. Dr., Necmettin Erbakan University, Health Science Faculty, Social Work Department, Konya, Turkey kubrakucuksen@yahoo.com
} 


\section{Introduction}

Gender is "a concept used to point out the roles created socially for women and men and learnt behavior expectations" (Ecevit, 2003: 83). When we look at the historical background of the concept, we see that it has emerged due to the inequalities existing in the societies and perception of woman as a secondary being. Gender covers the hierarchical structuring between men and women in terms of utilization of power, wealth and other resources. Therefore, the gender stratification, which is unequal distribution of wealth, power and privilege, has become one of the fields discussed in the social sciences in the recent years (Macionis, 2013, p. 328). The studies conducted in this field are seen to be addressed with three different approaches in a chronological order. In the first approach, it was accepted that the gender differences stem from biological difference, and in the second approach, socialization and learnt gender roles were emphasized. In the third approach, it was marked that gender has a central role in many fields from daily life such as family, law, development and education in all class and patriarchal societies (Ecevit et al., 2011, p. 4)

The concept of gender inequality refers to woman's being at secondary position in social life, social, economic, political fields, and having less place compared to men. In the historical process, place of women has been restricted to the private sphere (home) in all cultures, their presence in public sphere has become possible as a result of the challenges which have lasted for many years, and which are still going on. In the studies conducted after 1980, gender is evaluated together with the "gender roles".

Media has an important role in both visibility and reproduction of gender discrimination. In our age named as the communication age, we confront the social sharing sites, where gender roles and stereotype judgments are discussed with all their aspects, and which are designated also as new public sphere and new media, as the spaces where increasingly more participants share their opinions and comments within the framework of their own lifestyles and worldview. Due to the reasons that access is available at every hour of the day, people are allowed to freely express their real identities besides their idealized personalities, data and information flow is very fast; new media has reached a more advantageous position compared to other mass media.

In this study, it was aimed to investigate gender perception through the social sharing sites named Ekşi Sözlük and Uludağ Sözlük, the comments made on concepts of "gender", "gender equality/inequality" and "gender roles".

\section{Method}

The purpose of the study is to investigate gender perception of the society through Ekşi Sözlük and Uludağ Sözlük. The social sharing platforms discussed also as the new public sphere are a medium where a subject is discussed by persons having too different opinions with its different aspects, and as stated by Bilgin (2014, p. 240), they constitute a convenient application field in terms of examination of social / daily thought by means of content analysis or discourse analysis. One of the areas where ordinary person can express his/her thoughts about every field of the life from policy to daily life is the sharing dictionaries which develop day by day in virtual medium. The most important example of this is Ekşi Sözlük, which draws the attention with its posts that affect the country agenda from time to time. Ekşi Sözlük is site which broadcasts since 1999 with the slogan "kutsal bilgi kaynağı" ("holy information source"), where everyone can make comment with any identity and name they desire, which has reached a certain number of participants. It is stated that four billion pages have been viewed by 120 million different persons in 2013, that it has 900 thousand followers on twitter (wikipedia.com/eksi-sozluk). 
Uludağ Sözlük is a dictionary which has been established by İsmail Alpen, who uses the alias Zall, with the slogan "Ululardan Ulu Bir Sözlük" ("A Dictionary Greater Than The Greats"), which has terms and explanations updated by its members (wikipedia.org). Follow ranking of the site which had 203 thousand members as of March 2015 is the the thirtieth place according to the data of Alexa.com.

In this study, it was aimed to investigate the comments made on the concepts of "gender equality" and "gender inequality" on the social sharing sites named Ekşi Sözlük and Uludağ Sözlük. By entering "gender" word was made search ekşisözlük and uludag sözlük wide web. In the study, one hundred five comments made on Ekşi Sözlük and thirty nine comments made on Uludağ Sözlük in regard to the subject matter were categorized and analyzed as "gender equality", "gender inequality" and "gender roles". For analyzing data, content analyzis was applied to comments. Therefore, researcher could grasp mentality of the participants.

\section{Gender (In)equality in Turkey}

The term of discrimination against women means any discrimination, exclusion or restriction based on gender, which aims or results in preventing grant of the human rights and fundamental freedoms based on equality of women and men in political, economical, social, cultural, personal or other fields to women, women's benefiting from or using these rights (www.ksgm.gov.tr/pdf/cedaw.doc).

Throughout the modernization process in Turkey, visibility of the change and transformation experienced in the last century has taken place mostly on women. Despite the change experienced in many fields, woman is still kept restricted to the private sphere, home, in our society. By accepting the primary group of woman as family, the society expects woman in the roles of mother and spouse. However, society attributes a high status degree to motherhood and spouse positions (Çelebi, 1990, p.10). As in the whole world, gender perceptions in Turkey leads to differences between women and men with respect to production, sharing and opportunities, and this difference prepares the ground for women's being at a secondary status and position in every field of the life. The inequality existing in different fields such as education, economy, policy is at a very high stage. According to the Annual Global Gender Inequality Report (2012) of the World Economic Forum, Turkey ranks in the 124th place among 135 countries.

Gender equality is a basic principle of democracy, and one of the prerequisites of sustainable development. Strengthening the society is underlain by the fact that strengthening the women who constitute half of the society is an important factor (TBMM Commission of Equality of Opportunities for Women and Men, 2012).

The idea of Gender Policy was first developed at the Third World Conference on Women, which took place in 1985 in Nairobi. Thereafter, in 2000, the United Nations has approved it as the third of the eighth goals set within the scope of the Millennium Development Goals. As required by the Convention on the Elimination of All Forms of Discrimination against Women (Cedaw), which Turkey is a party to since 1986, it is ought to take any and all measures including legal arrangements in all fields, particularly in social, political, economic and cultural fields, in order to fully ensure women's development and advancement in education and development, to secure their fundamental rights and freedoms and ensure exercise of the same (www.Ksgm.gov.tr/pdf/cedaw.doc).

The 191 countries which participated in the Millennium Summit held in September 2000 made the decision of achieving the Millennium Development goals, including "to encourage gender equality 
and to ensure strengthening of women" until 2015. Turkey is among these countries (http//www.undp.org.tr/Gozlem3.aspx?web page no=248).

The General Directorate of Status of Women, which functions as a unit affiliated to the Ministry of Family and Social Policies, has prepared the National Action Plan on Gender Equality (2008-2013) in order to strengthen women, who are considered to be in the disadvantageous group, to ensure equality and justice in education, employment, and accessing and sharing economic resources. In this context, policy documents have been prepared in 7 critical fields (education, health, economy, participation in authority and decision processes, poverty, media and environment). However, despite the judicial and legal arrangements, a desired, remarkable development could not have been achieved practically since mentality transformation could not have been achieved.

In recent years, the concepts of equity and justice have started to come to the forefront rather than equality or inequality between women and men in Turkey. Gender is one of the concepts brought in to the literature by the western feminist discourse. Considering the historicalness of the social values, it is emphasized that the values and culture of the society lived in is taken into account, that a justice-centric approach should be developed (Güç-Işık, 2015:p 104). In gender, when "equity" or "justice" is spoken of, it is accepted that women and men have different requirements and power, apart from these differences, the view of distribution of the responsibilities and opportunities equally between the two genders is adopted (Zeyneloğlu, 2008, p.8). With the presupposition that being equal in every field does not ensure justice, justice in gender evokes the meanings of balancing the in-family and social roles of women and increasing the representation rate of women in political, social and economic development.

Today, for a fair, developed Turkey, it is required to regard all kinds of discrimination made against women as a human rights issue, to accept gender equality as the requirement of social justice in accessing the opportunities and benefiting from the resources.

\section{Results}

According to results, about "gender" was made 105 comments on Ekşi Sözlük and 39 comments on Uludağ Sözlük. We will be analyzing the results under the subheadings of gender equality/inequality and gender roles. In the pages concerning gender, a total of five hundred comments have been made on Ekşi Sözlük, gender equality has been discussed under four headings. These headings are "gender index", "association of monitoring gender equality", "gender equality" and "gender equality of Lego". Gender inequality has been opened up for discussion under the headings of "gender inequality", "global gender inequality" and "inequality of gender roles of women and men". The dictionary contains entries giving academic information about the concept. Gender roles have been discussed under the headings of "inequality of gender roles of women and men".

On Uludağ Sözlük, thirty nine comments have been made under three headings for the concept of gender. Gender (twenty comments) has found place with the headings of gender equality (ten comments), gender roles (three comments) conventional role of women in gender (four comments).

\section{Gender Equality}

In this field, the definitions regarding the concept have usually been interpreted through being linked to the events involving woman murders, violence against women and kid brides. The discussions where there is intense information sharing have mainly been made whether gender 
equality exists in Turkey. While swear and insult is also encountered, posts have been made such as the place of Turkey in the ranking of United Nations Gender Equality, the ranking of five provinces which are best and the five provinces which are worst in terms of equality. There are also critical comments in regard to this issue as to that laws need to be promulgated in the first place, that this issue is more important than the improvements made in economic fields. Moreover, information is shared by giving the links of the departments where lessons are thought at the universities and of the certificate programmes. However, it is clearly understood from the comments made in the dictionaries that the society does not have sufficient knowledge and awareness in this regard. Comment of a participant who is understood to be a teacher is as follows:

"This is the name of the lesson were are ordered by the Ministry of National Education to teach to the students and their mothers in order to prevent violence against women. "gender equality". It is seems that we are required to mention of the statistics reports, what a woman can do when she is exposed to violence, they handed me the letter, there is no choice, we will do it. I researched a little and tried to prepare a slide that will not bore them.... I say to the esteemed government, 'would you mind if you first educate your judges, prosecutors, police forces"' (eksisi sö̊lïk.com)

The comments made on Uludağ Sözlük rather contain a discourse against equality of women and men. A comment made by a member emphasizes a holistic right concept advocating human rights for men while on the other hand showing that he does not refrain from a language which is insulting for women.

"It is impossible to understand why and how the mentality that makes the man take the bill, wants bim to hold her chair, is not sent alone home at night asks for equality". "We live in such a country where men are oppressed and despised, work in worst jobs, burnt alive in the mines. Gender equality cannot be established without securing men's rights (Uludağsozluk.com)

Gender inequality is not contained as a heading on Uludağ Sözlük, whereas it is discussed with 58 comments on Ekşi Sözlük.

It has been commented that equality basically results from not sending girls to school, that they cannot join business life since they lack education, that the work they do does not have exchange value and monetary value although they constantly work in the field and at home. It is seen that the discussions in this field are mostly made on gender roles. There are comments expressing that this situation is not specific to Turkey, that the the understanding accepted in all societies in the historical process date back to centuries ago. A participants interprets this understanding as follows.

"This logic comes from Plato. The Master says that woman represents emotions and men represents reason. In other words, women are the symbol of nature and men are the symbol of civilization. Consequently, everything that is natural, eating, drinking, cleaning, even reproducing, is the task of women, whereas the things brought by the civilization, i.e. working, earning money, science, politics, are the duty of men. While woman lives at home, man establishes the civilization. The task falling to women is to deliver and feed the men who establish and sustain the civilization .." (Ekesisöglïk.com)

A member who says that both parties may have strengths and weaknesses, that they do not have to be necessarily equal, has made the comment "Women shall do everytbing that men do. For instance, all minibus drivers shall be male, or women shall run after men, and men shall put on airs like stupid. I mean, what is expected, is it necessarily required to be equal?", emphasizes that inversing the process functioning in the society might lead to undesired results for women, as well.

On another platform, the discussion starting with the woman perception of men shows that senders of the post have a biased and negative viewpoint against women. It is possible to see this in the following comment of a participant.

"When you look at an ordinary woman, the situation is a little desperate. They only go to shopping and check clothing for five hours, come together with their other friends and gossip about another friend 

doi:10.14687/ijhs.v13i1.3565

of theirs, monkey around with senseless things like makeup and dress match for a few hours a day, shoot forty photos to put photos on Instagram and run after likes saying "girlz: I uploaded new photo to instagram to the group on whatsapp..." (Ekesisözlïk.com)

These and other similar discourses reveal the mental background as to that women lack the knowledge and competence to deserve the same position with men in the society.

In the dictionary, it is also remarked that Turkey ranks in the last 20th place in the of the gender inequality ranking (Oh Turkey, the great state, look at these statistics before the debt to IMF), and it is emphasized that this issue is one of the most important problems of the country.

\section{Gender Roles}

It has been discussed for a long time that the gender roles are a process of construction. In the historical process, although women have been in the focus of the production activities in all societies, a secondary value behind men has been attributed to their labor. According to the understanding that regards the gender roles as a reflection of the male-dominant capitalist system; women have been confined to the domestic private sphere and restricted to the works with production value but without monetary exchange value such as cooking, looking after children, and their labor has been trivialized. Even if they work in public sphere, they lag behind men in terms of wage and status. Man holds the right to establish dominance over the woman as the person who works in public sphere and wins the bread. The gender stereotypes determined in this way deprives women of their freedom and restrict them and what they will do on one hand, while on the other hand increase burden of the men with the tasks and responsibilities attributed to men, and consequently, make life too difficult for both parties (Yumlu, 2014). In this regard, a comments shared on Uludağ Sözlük under the heading of conventional role of women in gender is very remarkable.

"Woman is the one who shoulders the concept of honor in Turkish society. She has no country since birth. There is father's home and husband's home for her. She does not belong to the father's home, she is there in trust. She will not carry her surname anyway. At busband's home, she is the girl of others, a maid, always a mother. Never a woman. There are lots of rules on how she is ought to be. She is not as free as a man. Her role is a support force for man." (Uludagsozluk.com)

On Ekşi Sözlük, the discussions that gender roles are taught in the family beginning from birth and reinforced by society are seen to be carried on over a toy company. The Lego sets assign different roles to the genders (e.g. Legos with Barbie) have been criticized, critics have been made to the effect that the producer company should not produce "girls' toys" and "boys' toys", but "kids' toys" without contrasts.

On Ekşi Sözlük, it is widely accepted that the inequality of gender roles results from the stereotype judgements about gender roles in the society. According to Mary Wollstonecraft, a feminist pioneer, "instigation of sensualities, weaknesses of women, their identification with fragility, passivism and dependence in the society, which is the existing situation, serve to their being kept at inferior position and confined to home" (Ecevit et al. 2013). In the comments made on Ekşi Sözlük, it is asserted that the judgments like "women are elegant, women are fragile", which are perceived as a positive viewpoint on women, push women to a secondary, weak position, that they reinforce the stereotypes of woman "in need of protection and love" and "powerful", "possessive" man. A participant who states that such stereotype judgments also impose a heavy burden to men time expresses that men are uncomfortable with the judgments such as "women do not take the bill", "men always have to work", "women may stay at home, there is no problem with this".

Another participant who defines the current situation as an existing, ongoing inequality has expressed his opinions as "in order to eliminate this inequality, it is required to equalize the justice, i.e. to treat fairly, to be buman, to equalize the opportunities, instead of trying to equalize women and men. Not sending girls to 
school, giving them in marriage at little age, making them marry a man without their consent, asking them to act as slave for their husbands, ruining their lives do not fit logic, reason or religion". This comment shows that the participant approaches equality of women and men with a superior viewpoint beyond equality, with the sense of justice and equity.

Another interesting subject discussed under the heading of gender roles on Ekşi Sözlük has been opened up for discussion under the heading "hair from the aspect of gender roles". Under this heading containing only two comments, a participant criticizes where women always have to have ideal sizes and be beautiful. "The hair on woman's body is always is a threat for men; the discomfort caused by this threat is estheticized, discomfort of men is diverted from its course and turned into an esthetic obligation of women. Just like the "obligation of losing weight", the obligation of "being hairless" becomes part of daily life of women. (Eksisisǫ̈lïk.com)

The comments shared on Uludağ Sözlük under the heading of conventional role of women in gender express the discomfort existing in the society, suggest interrogation of the family structure, the fundamental institution of the social structure, for solution.

"Conventional role of woman is unfortunately motherhood. Visibility of woman in the society is based on her getting married and becoming mother. When you object to these, some people twaddle about tradition, customs, and morals. Woman is expected to devote herself to her family, not to her career. And those who have a career feel themselves inadequate if they are not a mother. If social position of women will be changed, this should be started from the criticism of family structure."

A participant stressing that reinforcing the stereotype judgments reinforcing the equality which is widely accepted in the society states that the task of ensuring equality and justice falls to women.

"In the picture we often confront in television commercials, women are usually responsible for housework, child care, whereas men are reflected as the head of the family. In that case, the task falls to women. Occurrence of changes is unthinkable unless women revolt against to this order. For the change to become real, raising awareness of women beside education is essential. As long as there are masochist women who do not allow anything to be said against their sons, make their sons' bed, pack his suitcase, spend their hours to cook all favorite foods of their sons; this distribution of tasks based on gender will go on for so long (ekșisözlïk.com).

\section{Conclusion and Discussion}

The concept of gender expresses that womanhood and manhood are culturally constructed, learnt items rather than biologic differences. The foundation of the problem of (in)equality discussed between women and men is based on ideological, political, economic and cultural structures. The field where this problem is most visible is women's being deprived of and exclusion from public sphere. In the historical process, position and function of women have been restricted to domestic private sphere in the entire world.

Gender perception of the society through Ekşi Sözlük and Uludağ Sözlük was investigated in this study. The most important features of social sharing sites are that the individuals can freely share all their opinions and thoughts without any reservation. Women are the disadvantageous group in terms of access to new communication technologies. Although the rate of use by women has increased in the recent years, the difference between them and men has remained unchanged (TÜIK, 2011). When the comments made in the dictionaries with regard to the subject, he comments made by male participants are seen to be more.

Since the mentality transformation required for the reforms could not have been achieved despite many legal and judicial arrangements in Turkey in the recent years, the equality, equity or justice of 
women and men could not have been fully achieved as desired. Reflections of the conventional patriarchal mentality are evidently seen in the comments on Ekşi Sözlük and Uludağ Sözlük.

According to the data attained from analysis of the study, as opposed to conventional media, it is seen that the comments made on gender are quite varied. Besides such comments which reduce women merely to a body, insult them, assert that they lack the knowledge, skills and competence for existing in the public sphere, comments exceeding the equalitarian viewpoint on the subject, grounding on justice and equity have been identified.

With the presumption of being equal in all areas does not provide justice; gender equality connotes balancing the family and social roles of women and increasing the rate of their representation in political, social and economic areas. Today, for a fair and developed Turkey, it is necessary to consider any kind of discrimination against women as a human rights issue, and gender equality in accessing the opportunities and utilizing from sources must be accepted as a condition for social justice.

As an institution having the power of reconstructing gender, new media contents need to be reviewed again. Society should be aware about gender through the new media

\section{Bibliyografya}

Bilgin, N., (2014). Sosyal Bilimlerde İçerik Analizi Teknikler ve Örnek Çalışmalar. 3. Baskı. Ankara: Siyasal

Binark, M., Gencel M., (2007). Eleştirel Medya Okuryazarllğı Kuramsal Yaklaşımlar ve Uygulamalar. İstanbul: Kalkedon

Çelebi, N. (1990). Kadınlarımızın Cinsiyet Rolü Tutumları, Konya:Sebat

Demez, G. (2005). Değisen Erkek İmgesi. İstanbul: Babil

Ecevit Y., vd. (2011). Toplumsal Cinsiyet Sosyolojisi, (Ed. Y. Ecevit, N. Karkıner ) Eskişehir : Anadolu Üniversitesi Açık Öğretim Fakültesi. No.1304

Ecevit, Y., (2003). Toplumsal Cinsiyetle Yoksulluk İliskisi Nas1l Kurulabilir? Bu İliski Nasıl Çalısılabilir?, Cumhuriyet Üniversitesi Tip Fakültesi Dergisi, Sayı: 25.

Güç-Işık, A. (2015). İslâm, Kadın ve Toplumsal Cinsiyet Adaleti İslâmi Bakış Açısından Bir kavramlaştırma Denemesi, Toplumsal Cinsiyet Adaleti Kongre Kitapçı̆̆ı, s.104-109.

Macionis, J.J., (2013). Sosyoloji (Çev.ed. Vildan Akan ) 13. Baskı. Ankara : Nobel

TBMM Toplumsal Cinsiyet Essitliğinde Medyanın Rolü Raporu (2012). Kadın Erkek Fırsat Eşitliği Raporu, No.10 Ankara : $\quad$ TBMM Basimevi (http//www.tbmm.gov.tr/komisyon/kefe/index.htm)

Yumlu G. (2014). Toplumsal Cinsiyet ve Medya Ankara: Detay

Zeyneloğlu, S., (2008). Ankara’da Hemşirelik Öğrenimi Gören Üniversite Öğrencilerinin Toplumsal Cinsiyet Rollerine İlişkin Tutumlan, Doktora tezi, Hacettepe Üniversitesi,

http://www.ksgm.gov.tr/uluslararasi Belgeler cedaw.php\#(accsed on: 10 Mart 2011)

https://eksisozluk.com/toplumsal-cinsiyet-rolleri--3392539 (accesed on: 4. 09. 2015)

https://eksisozluk.com/toplumsal-cinsiyet-esitligi--3144119 (accesed on: 11.09. 2015)

https://eksisozluk.com/cinsiyet-esitsizligi--1532541(accesed on : 11.09.2015)

(http://www.undp.org.tr/Gozlem3.aspx?.Web-SayfaNo=248(accesed on 30.08.2015)

https://tr.wikipedia.org/wiki/Eksi Sözlük

http:/ / www.uludagsozluk.com/toplumsal-cinsiyet-e $\%$ C5 $\% 9 \mathrm{Fitli} \% \mathrm{C} 4 \% 9 \mathrm{Fi} /$ (accesed 13.09.2015

on:

http://www.uludagsozluk.com/k/cinsiyet-rolleri/(accesed on : 13.09.2015 ) 